\title{
Five Times Weekly
}

National Cancer Institute

\section{Source}

National Cancer Institute. Five Times Weekly. NCI Thesaurus. Code C85552.

Five times per week. 